\title{
Memahami Kekerasan Seksual sebagai Menara Gading di Indonesia Dalam Kajian Sosiologis
}

\author{
${ }^{1}$ Ariani Hasanah Soejoeti, ${ }^{2}$ Vinita Susanti \\ Magister Kriminologi, Fakultas Ilmu Sosial dan Ilmu Politik, Universitas Indonesia \\ Departemen Kriminologi, Fakultas Ilmu Sosial dan Politik, Universitas Indonesia \\ ariani.soejoeti@gmail.com, vinitasusanti@yahoo.com
}

\begin{abstract}
Many studies on campus sexual assault in the past use lifestyle-routine activities theory to explain the crime. According to those studies, certain lifestyle factors can increase the likelihood of victimization while still in college. Our research shows that the two theories fail to explain that several institutional policies or regulations set by universities can limit and shape an individual's lifestyle, thus increasing the risk of victimization. These policies or regulations include class schedules, thesis consultancies, and campuscommunity service programs. Against this background, the authors argue that the root cause of campus sexual assault lies in the patriarchal culture in the Indonesia context hence women have a higher risk of victimization than men.
\end{abstract}

Keywords: sexual assault, patriarchy, victimization, feminist, sociology

\section{PENDAhUluan}

Sejumlah penelitian menunjukkan bahwa kejahatan di kampus relatif bermasalah, tetapi risiko kekerasan seksual adalah sebuah epidemi (Franklin et al., 2011). Selanjutnya, beberapa penelitian terdahulu menyatakan bahwa pelaku dari kekerasan seksual di kampus perguruan tinggi sering kali adalah orang yang sudah dikenal oleh korban (Bondurant, 2001; Banyard et al., 2005; Forbes et al., 2005). Orang yang dikenal ini tidak hanya teman sebaya korban (seperti teman kuliah atau pacar) tetapi juga bisa orang yang mereka hormati seperti profesor atau dosen pembimbing (Garlick, 1994; Lee et al., 2005).

Selain itu, beberapa penelitian lain menemukan bahwa dalam beberapa kasus kekerasan seksual, lembaga perguruan tinggi terkait diidentifikasi sebagai kaki tangan dari insiden tersebut (Fitzgerald et al., 1988; Dziech and Weiner, 1990; Grauerholz et al., 1999; Eyre, 2000). Eyre mengatakan bahwa hal tersebut dikarenakan adanya relasi kuasa di lembaga tinggi dalam membingkai kasus pelecehan seksual yang pada akhirnya melegitimasi tindakan pelecehan seksual. Sejumlah penelitian juga 
menemukan bahwa perempuan yang paling berisiko menjadi korban dibandingkan lakilaki (Holland, 2017). Selanjutnya, penelitian lain juga mengungkap bahwa perempuan memang mempunyai kecenderungan menjadi korban daripada laki-laki, terutama pelecehan seksual klasik seperti sentuhan yang tidak diinginkan dan invasi pada ruang pribadi (Uggen and Blackstone, 2004).

Dalam konteks Indonesia, beberapa insiden kekerasan seksual yang terjadi di kampus yang mencuat di media massa telah menjadi sorotan publik. Kita dapat melihat dalam beberapa tahun belakangan ini kekerasan seksual di kampus menjadi berita utama di berbagai media massa. Menurut penulis, hal tersebut dapat menciptakan kesan bahwa kampus adalah tempat yang semakin berbahaya, terutama bagi perempuan. Namun demikian penulis mengamati bahwa data statistik formal yang secara khusus melaporkan angka kekerasan seksual yang terjadi di kampus-kampus di Indonesia belum tersedia. Data yang tersedia kebanyakan berasal dari survei korban yang dilakukan secara independen dan masih bersifat sporadis. Beberapa data yang dimaksud penulis tersebut antara lain adalah \#LaporanNamaBaikKampus (Zuhra, 2019) dan data yang disebutkan dalam Surat Keputusan (SK) Direktur Jenderal Pendidikan Islam (Dirjen Pendis), Kementerian Agama (Kemenag), Nomor 5494 Tahun 2019 tentang Pedoman Pencegahan dan Penanggulangan Kekerasan Seksual pada Perguruan Tinggi Keagamaan Islam (Direktur Jenderal Pendidikan Islam Kementerian Agama RI, 2019). Selain itu, ketersediaan penelitian ilmiah yang fokus terhadap isu kekerasan seksual di kampus masih sangat terbatas.

Secara teoritis, merujuk pada penelitian terdahulu, banyak penelitian terkait kekerasan seksual di kampus menggunakan pendekatan teori gaya hidup-kegiatan rutin (lifestyle-routine activity theory). Para peneliti tersebut menyatakan bahwa faktor gaya hidup tertentu dapat meningkatkan kemungkinan viktimisasi ketika masih kuliah. Salah satu penelitian terdahulu mengatakan bahwa indikator peluang tersebut_perilaku gaya hidup dan kegiatan rutin dapat meningkatkan eksposur dan kedekatan seseorang dengan pelaku yang termotivasi, meningkatkan daya tarik seseorang sebagai target, dan mengurangi kemampuan pengamanan seseorang. Hal tersebut kemudian memengaruhi risiko kekerasan seksual saat di perguruan tinggi (FISHER et al., 1998).

Selanjutnya, penelitian lain mengukur frekuensi perempuan perguruan tinggi yang pergi minum-minum, dan apakah mereka memiliki teman yang cenderung membuat perempuan mabuk dengan harapan akan seks. Hal tersebut dilakukan untuk menjelaskan mengapa kekerasan seksual dapat terjadi (Schwartz and Pitts, 1995). Lalu bagaimana dengan rutinitas yang "terpaksa" dilakukan?

Berangkat dari permasalahan tersebut, penulis berpendapat bahwa teori paparan gaya hidup-aktivitas rutin belum mampu memberikan penjelasan tentang kebijakan yang mengatur ekspektasi peran dan kendala struktural. Ada beberapa kebijakan kelembagaan atau peraturan yang ditetapkan oleh perguruan tinggi. Misalnya, jadwal perkuliahan, bimbingan skripsi/ tesis, KKN dan lain sebagainya. Aturan-aturan ini dapat 
membatasi dan membentuk gaya hidup individu, sehingga mengarah pada peningkatan risiko viktimisasi. Dari pemikiran tersebut, argumen yang penulis ajukan adalah dalam konteks Indonesia, akar permasalahan dari mengapa kekerasan seksual terjadi di kampus bukan terletak pada gaya hidup atau aktivitas seseorang tetapi pada kuatnya budaya patriarki dalam masyarakat sehingga secara alami, perempuan memiliki risiko viktimisasi lebih tinggi daripada laki-laki. Untuk menguji argumen tersebut, penulis melakukan sebuah penelitian dengan menggunakan pendekatan kritis dari perspektif kriminologi feminis. Penjelasan lebih rinci terkait penelitian akan dijelaskan pada bagian metode penelitian.

Selanjutnya, mengingat bahwa masih terbatasnya literatur ilmiah yang fokus terhadap kekerasan seksual di kampus, maka selain untuk memberikan kontribusi dalam pengembangan literatur ilmiah dalam bidang studi kriminologi, artikel ini juga bertujuan selain untuk mengundang para dosen, peneliti dan praktisi untuk bergabung dalam diskusi terkait melalui publikasi karya ilmiahnya. Harapannya, kekerasan seksual dapat dientaskan melalui kebijakan pencegahan dan penanggulangan yang mumpuni.

\section{TINJAUAN PUSTAKA}

\section{Kekerasan Seksual}

Definisi kekerasan seksual bervariasi, namun demikian pada umumnya, kekereasan seksual menggambarkan serangkaian aktivitas seksual yang sifatnya dipaksakan atau dilakukan tanpa persetujuan. Aktivitas tersebut termasuk di antaranya kontak seksual (misalnya cumbuan dan ciuman), pemaksaan seksual secara verbal, percobaan maunpun pemerkosaan lengkap. Definisi hukum dari aksi perkosaan bervariasi, namun demikian pada umumnya aksi tersebut didefinisikan sebagai penetrasi vagina atau anus (oleh penis, bagian tubuh lainnya, atau benda) dan seks oral yang diperoleh dengan kekerasan, ancaman kekerasan, atau ketika korban dalam keadaan tidak mampu/ tidak sadarkan diri (Holland, 2017).

Selanjutnya, kekerasan seksual juga dapat diwujudkan dalam bentuk kekerasan simbolik (Bourdieu, 1990). Bourdieu menjelaskan bahwa kekerasan simbolik masuk dalam jenis-jenis kekerasan non-fisik yang muncul dalam perbedaan kekuatan antara kelompok sosial. Menurut mereka, bentuk kekerasan secara tidak sadar disetujui oleh kedua belah pihak. Namun demikian, terlihat bahwa kecenderungannya adalah adanya pemaksaan norma-norma oleh kelompok yang memiliki kekuatan sosial yang lebih besar terhadap kelompok sosial yang lebih lemah. Kekerasan simbolik tersebut dapat dimanifestasikan di berbagai domain sosial seperti kebangsaan, gender, orientasi seksual, atau identitas etnis.

Selain itu, beberapa penelitian terdahulu juga mengungkap bahwa efek dari kekerasan seksual bersifat jangka panjang, khususnya efek psikologis. Selanjutnya mereka juga mengatakan bahwa beberapa penelitian terdahulu juga menemukan bahwa kondisi tersebut diperkeruh oleh viktimisasi sekunder (baca: viktimisasi ganda) yang 
korban peroleh ketika melaporkan tindak kekerasan seksual yang dialaminya. Seringkali korban disalahkan dan dianggap berkontribusi terhadap terjadinya kekerasan seksual tersebut. (Wolhuter, Olley and Denham, 2008)

Sementara itu, yang dimaksud dengan kekerasan seksual di kampus oleh penulis adalah kekerasan seksual yang terjadi di ranah lembaga perguruan tinggi dan/ atau yang berhubungan dengan lembaga perguruan tinggi tersebut. Artinya, kasus-kasus kekerasan seksual itu terjadi di kampus dan/ atau dilakukan oleh/ terhadap sivitas akademika atau terjadi di luar kampus tapi dalam acara-acara resmi, seperti KKN, magang, atau acara kemahasiswaan.

\section{Pembahasan : Kajian Sosiologis dalam Memahami Kekerasan Seksual Lifestyle-Routine Activity Theory}

Selama beberapa dekade terakhir, penelitian terkait kekerasan seksual di AS, khususnya tentang viktimisasi seksual, mengungkap hubungan antara risiko viktimisasi dengan gaya hidup dan aktivitas tertentu. Gaya hidup dan aktivitas tersebut antara lain adalah, budaya pesta kampus, konsumsi obat terlarang dan minuman beralkohol. (Elvey, 2016)

Teori paparan gaya hidup dan aktivitas rutin pada awalnya merupakan dua konsep teori yang berbeda. Menurut Elvey, para viktimolog menemukan banyak kesamaan antara kedua teori tersebut sehingga kemudian terbentuk suatu asumsi bersama untuk menggabungkan keduanya menjadi teori gaya hidup-aktivitas rutin. Dalam menjelaskan pandangannya tersebut, Elvey merujuk pada beberapa literatur ilmiah seperti Gorofalo (1987), Cohen dan Felson (1979), serta Hindelang et al. (1978), Cohen, Kluegel, dan Land (1981). Menurut Elvey, ada empat konsep spesifik yang berkontribusi pada viktimisasi: kedekatan dengan kejahatan, pemaparan terhadap kejahatan, daya tarik sasaran, dan kurangnya kemampuan perwalian.

Dalam konteks penelitian terkait kekerasan seksual di kampus, Elvey melakukan identifikasi terhadap penelitian empiris yang relevan dalam kurun waktu tahun 1995 2016 dan menemukan bahwa teori gaya hidup-aktivitas rutin dapat didukung. Menurutnya, teori tersebut terbukti menjadi pendekatan yang berguna untuk memahami viktimisasi seksual mahasiswa/ mahasiswi. Meskipun demikian, Elvey juga menyadari bahwa teori tersebut memiliki keterbatasan. Pertama, Ia menemukan bahwa banyak mahasiswa/ mahasiswi yang berpartisipasi dalam gaya hidup maupun aktivitas yang menjurus pada hedonisme (pesta pora, mabuk-mabukan) namun tidak menjadi korban kekerasan seksual. Kedua, Elvey melihat bahwa teori gaya hidup-aktivitas rutin sepertinya dirancang untuk menjelaskan risiko viktimisasi mengenai kejahatan predator, sementara data empiris mengungkap bahwa sebagian besar viktimisasi seksual terjadi di tangan anggota keluarga, pasangan intim, dan kenalan. 
Community: Volume 6, Nomor 2, Oktober 2020

p-ISSN: 2477-5746 e-ISSN: 2502-0544

\section{Relasi kuasa antara korban-pelaku}

Meski pada hakikatnya semua manusia yang dilahirkan ke dunia ini memiliki nilai yang sama, namun tidak dapat dipungkiri bahwa dalam kehidupan bermasyarakat, individu maupun kelompok tertentu memiliki kuasa (baca: kekuasaan) terhadap individu maupun kelompok lainnya. Dalam kehidupan bermasyarakat kita dapat melihat bagaimana status sosial, jenis kelamin, ras, agama dan kedisabilitasannya seringkali mempunyai pengaruh dalam interaksi sosial.

Pengertian Weber akan kekuasaan adalah bahwa kekuasaan merupakan sesuatu yang sebenarnya digunakan dalam sebuah hubungan permusuhan dan melibatkan konflik antara individu/ kelompok yang berkuasa dan yang tidak (Wallimann, Tatsis and Zito, 1977). Disebutkan juga oleh mereka bahwa ada tiga jenis otoritas dari mana kekuasaan berasal, yaitu tradisional (patriarkal, patrimonial), karismatik (otoritas yang didapat dengan kemampuan karismatik yang dapat memengaruhi orang lain), dan hukum/ rasional (otoritas yang diberlakukan secara formal oleh pemerintah atau pada tingkatan yang lebih mikro seperti hubungan atasan dengan bawahan). Menurut mereka, sosiolog ternama Peter M. Blau mengartikan definisi kekuasaan Weber sebagai kemampuan seseorang untuk memaksakan kehendaknya pada orang lain meskipun ada perlawanan.

Berdasarkan uraian di atas, maka dapat dikatakan bahwa relasi kuasa korbanpelaku dapat diartikan sebagai kemampuan pelaku untuk memaksakan kehendaknya terhadap korban meskipun ada perlawanan. Dalam konteks penelitian ini, yaitu kekerasan seksual di kampus, maka relasi kuasa antara korban-pelaku yang dimaksud peneliti adalah relasi yang ditentukan oleh kekuasaan laki-laki, atau yang telah disebut di atas, yaitu tradisional patriarkal.

\section{Budaya Patriarki}

Banyak teoritisi feminis menyatakan bahwa budaya patriarki merupakan salah satu penyebab utama penindasan terhadap perempuan (Murray, 1995). Menurut Murray, meski konsep patriarki ini ditentang oleh sebagian feminis, namun sebagian besar feminis lainnya menganggap bahwa budaya patriarki memberikan definisi sifat subordinasi laki-laki terhadap perempuan. Ia menyebutkan bahwa Shulamith Firestone adalah salah seorang penafsir terkemuka yang revolusioner dalam pengembangan analisis feminis radikal tentang ketidakseimbangan kekuatan seksual yang beroperasi dalam kepentingan laki-laki. Dalam artikel jurnalnya tersebut, Murray mengatakan bahwa Firestone mendefinisikan patriarki sebagai suatu sistem penindasan terhadap perempuan. Sistem penindasa tersebut terbentuk karena adanya ketimpangan faktor biologis antara laki-laki dengan perempuan, terutama dicontohkan dalam kemampuan perempuan untuk mengandung dan melahirkan anak, di mana laki-laki tidak bisa melakukannya. Oleh karenanya, perempuan harus mendapatkan kendali atas reproduksi agar bebas dari penindasan dari laki-laki. 
Pandangan yang berbeda datang dari Sylvia Walby. Dalam bukunya yang berjudul, "Theorizing Patriarchy", Walby mendefinisikan patriarki sebagai sistem struktur sosial dan praktik di mana laki-laki mendominasi, menindas dan mengeksploitasi perempuan. Walby berpendapat bahwa budaya patriarki terbentuk karena adanya beragam praktik, baik dalam ranah privat maupun publik yang mengakar dalam sistem tradisi budaya dan agama di mana perempuan menjadi subyek yang direndahkan atau berada di bawah kekuasaan laki-laki. (Walby, 1989)

Di tahun yang sama, pandangan Walby tersebut mendapat kritikan dari Joan Acker. Kritikan Acker adalah kekhawatirannya bahwa patriarki sudah dijadikan sebagai fenomena universal yang trans-historis dan trans-kultural di mana perempuan selalu ditindas oleh laki-laki dalam kurang lebih cara yang sama, yaitu cenderung menuju esensialisme biologis. Menurut Acker, patriarki bukanlah sebuah konsep analitis yang efektif dan sebaiknya ilmu sosial feminis bergerak ke arah yang berbeda. Meskpin demikian, Acker juga menyadari bahwa ada bahaya dalam meninggalkan konsep patriarki, terutama dalam peralihannya menuju penggunaan konsep gender. Menurutnya peralihan tersebut justru dapat melemahkan perkembangan pemikiran feminis. (Acker, 1989)

Dalam konteks penelitian ini, maka penulis akan mengadopsi kedua pandangan Firestone (1970; dikutip oleh Murray, 1995) dan pandangan Walby (1989), dan melihat budaya patriarki sebagai suatu sistem penindasan terhadap perempuan, baik disebabkan karena adanya ketimpangan faktor biologis antara laki-laki dengan perempuan maupun terbentuk karena adanya beragam praktik, baik dalam ranah privat maupun publik yang mengakar dalam sistem tradisi budaya dan agama di mana perempuan menjadi subyek yang direndahkan atau berada di bawah kekuasaan laki-laki.

\section{Teori Feminis Radikal}

Feminisme radikal menempatkan kekerasan laki-laki terhadap perempuan dalam agenda kriminologis (Walklate, 2007). Menurutnya, secara historis, bersamaan dengan berkembangnya gerakan feminisme di tahun 1970-an, pemikiran feminis radikal tersebut muncul sebagai ketidakpuasan terhadap pemikiran radikal Sosialis dan radikal Marxis.

Pemikiran feminis radikal ini kemudian berkembang menjadi dua aliran besar, yaitu feminis radikal libertarian dan feminis radikal kultural. Keduanya mempunyai pendekatan yang berbeda dalam mengkampanyekan gerakan memerangi seksisme (Tong, 2009). Namun demikian, Valerie Bryson mempunyai pendapat lain. Bryson berpendapat bahwa secara umum, feminis radikal melihat bahwa penindasan terhadap kaum perempuan bukan pada organisasi sosial tetapi lebih pada kontrol laki-laki terhadap budaya, agama bahasa dan pengetahuan yang membatasi pola pikir masyarakat. Bryson mengatakan bahwa pada akhirnya, konsepsi patriarkal 
diinternalisasi oleh perempuan maupun laki-laki dan menjadi pola relasi dalam hidup bermasyarakat. (Bryson and Bryson, 1992)

Dalam pandangan penulis, inilah yang kemudian melatarbelakangi bagaimana wacana terkait pemerkosaan kemudian dibingkai ulang oleh kaum feminis radikal dengan menyatakan bahwa pemerkosaan merupakan tindakan dominasi laki-laki terhadap perempuan dan bukan didimotivasi secara individual namun lebih kepada tindakan politik. Beverly Mcphail mengatakan bahwa pada penelitian sebelumnya yang dilakukan oleh Melani \& Fodaski di tahun 1974, pemerkosaan bukanlah sekedar tindakan seksual belaka, namun dianggap sebagai suatu tindakan yang lebih agresif. Dalam artikel jurnalnya tersebut, Mcphail menyebutkan bahwa Melani dan Fodaski melihat adanya motivasi dan dinamika lain yang muncul dari tindakan kekerasan seksual, yaitu dominasi laki-laki terhadap perempuan. (McPhail, 2015). Artinya, kejahatan seksual dijadikan senjata bagi laki-laki untuk mendominasi perempuan.

Sejalan dengan pemikiran tersebut, Susan Brownmiler, dalam bukunya yang berjudul "Against our Will: Men, Women, and Rape", menyatakan bahwa tindakan pemerkosaan sangat erat hubungannya dengan konteks sosial dan politik. Brownmiller memandang semua pemerkosaan sebagai latihan kekuasaan, di mana fungsinya untuk mengintimidasi perempuan sehingga mereka akan selalu takut dan tunduk terhadap lakilaki. Menurutnya, kekerasan seksual adalah kejahatan berbasis gender, dengan perempuan lebih mungkin menjadi korban. Selain itu, Brownmiller mengatakan bahwa intimidasi seksual tersebut tidak mengenal perbedaan rasial. (Brownmiller, 2005). Atas pandangannya ini, Brownmiller sering dianggap sebagai orang pertama yang mengartikulasikan konsep budaya perkosaan atau dikenal dalam istilah bahasa Inggris, "rape culture"(Rentschler, 2014).

Pendekatan feminis radikal terhadap pemerkosaan meliputi antara lain tiga ciri, yaitu: kedaulatan tubuh perempuan dirampas; cakupannya melebihi dari sekadar kekuatan fisik dan kekerasan atau ancaman eksplisitnya; dapat menciptakan dan mereproduksi berbagai sistem dominasi termasuk patriarki, rasisme dan kolonialisme (Whisnant, 2007). Konsep "rape culture" inilah yang kemudian dijadikan sebagai dasar awal dalam membangun wacana terkait kekerasan seksual di kampus (Phillips, 2017).

Berangkat dari paparan di atas dan pengalaman penulis sebagai penyintas, maka penulis mengamati dalam konteks Indonesia, khususnya terkait kekerasan seksual di kampus, budaya patriarki yang masih sangat kuat dapat menjelaskan fenomena kekerasan seksual di kampus.

\section{METODE PENELITIAN}

Artikel ini merupakan sempalan dari penelitian tesis yang dilakukan oleh penulis utama, Ariani Hasanah Soejoeti yang berjudul, "Kekerasan Seksual di Kampus: Kebijakan Pencegahan dan Penanggulangan di Perguruan Tinggi X dan Y”. Adapun jenis penelitiannya adalah penelitian kriminologi feminis yang mengadopsi pandangan 
214

Community: Volume 6, Nomor 2, Oktober 2020

p-ISSN: 2477-5746 e-ISSN: 2502-0544

feminis radikal dengan penekanan penting terletak pada isu seputar seksualitas dan dominasi laki-laki terhadap perempuan. Selanjutnya, mengingat bahwa kekerasan seksual di kampus merupakan sebuah fenomena yang cukup kompleks yang terjadi dalam konteks sosial dan dipengaruhi oleh norma-norma gender, hubungan antarpribadi, dan naskah seksual, maka penulis menggunakan pendekatan kritis.

Untuk kepentingan artikel ini, penulis hanya menggunakan sebagian dari data primer pada penelitian induk yang dianggap relevan. Data primer tersebut adalah hasil wawancara dari 4 (empat) narasumber. Pengumpulan data primer dilakukan dengan menggunakan metode wawancara semi-terstruktur melalui medium telepon dan email, di mana untuk memperoleh data primer, penulis terlebih dahulu melakukan pemilihan narasumber secara purposif.

Narasumber yang dipilih adalah yang masuk dalam kriteria subyek penelitian, yaitu individu yang mempunyai pengalamanan terkait kekerasan seksual di kampus. Pengalaman ini berupa pengalaman langsung maupun tidak langsung atau keduanya. Pengalaman langsung antara lain termasuk menerima laporan/ aduan, melakukan pendampingan terhadap korban, melakukan konseling bagi korban maupun pelaku, dan menjadi ketua atau anggota tim satgas (investigasi maupun penyelesaian kasus). Sementara itu, pengalaman tidak langsung, antara lain termasuk mendengar kabar tentang adanya kekerasan seksual di kampus, mengikuti pelatihan terkait pencegahan dan penanggulangan kekerasan seksual di kampus, menjadi ketua atau anggota tim satgas dalam mengembangkan kebijakan pencegahan dan penanggulangan kekerasan seksual di kampus.

Keempat narasumber tersebut mempunyai latarbelakang yang berbeda-beda. Narasumber pertama adalah seorang konselor yang sudah bekerja menangani korban maupun pelaku selama kurang lebih dari 46 tahun. Narasumber kedua adalah seorang aktivis yang bekerja di salah satu lembaga layanan terhadap perempuan korban kekerasan seksual yang sudah mendampingi korban selama kurang lebih 25 tahun. Narasumber ketiga adalah seorang kriminolog dan narasumber keempat adalah seorang dosen yang berpengalaman mendampingi korban kekerasan seksual di kampusnya.

Selain data primer, penulis juga mengumpulkan sejumlah data sekunder yang penulis gunakan dengan menggunakan metode online desk review. Dengan metode tersebut penulis melakukan studi kepustakaan, baik berupa buku, jurnal, pemberitaan media, artikel website maupun penelitian terdahulu yang penulis anggap relevan.

\section{TEMUAN DAN PEMBAHASAN}

\section{Temuan}

Seperti yang telah disinggung pada bagian pendahuluan, data terkait angka kekerasan seksual di kampus sifatnya sangat sporadis dan berasal dari survei korban yang dilakukan secara independent. Dari kedua laporan yang penulis sebutkan 
sebelumnya, yaitu \#LaporanNamaBaikKampus dan SK Dirjen Pendis Kemenag, penulis merangkumnya dalam matriks berikut (Tabel 4.1).

Tabel 4.1: Data Kekerasan Seksual di Kampus (KSK) di Indonesia

\begin{tabular}{|c|c|c|c|}
\hline No & Deskripsi & Laporan \#NamaBaikKampus & Pendis Kemenag \\
\hline 1 & Angka KSK & 174 & 1.011 \\
\hline 2 & Korban & $\begin{array}{l}\text { Mayoritas perempuan berstatus } \\
\text { mahasiswi }\end{array}$ & $\begin{array}{l}\text { Mahasiswa/ mahasiswi (jenis } \\
\text { kelamin korban tidak } \\
\text { disebutkan) }\end{array}$ \\
\hline 3 & Pelaku & $\begin{array}{l}\text { Mayoritas laki-laki berstatus } \\
\text { dosen dan mahasiswa }\end{array}$ & $\begin{array}{l}\text { Mahasiswa, staff akademik, } \\
\text { dosen }\end{array}$ \\
\hline 4 & $\begin{array}{l}\text { Tempat } \\
\text { kejadian }\end{array}$ & $\begin{array}{l}\text { Mayoritas terjadi di lingkungan } \\
\text { kampus, luar kampus tapi } \\
\text { dalam acara resmi seperti } \\
\text { magang atau KKN, online }\end{array}$ & Tidak disebutkan \\
\hline 5 & $\begin{array}{l}\text { Respon } \\
\text { korban }\end{array}$ & Mayoritas tidak melapor & Mayoritas tidak melapor \\
\hline 6 & $\begin{array}{l}\text { Cakupan } \\
\text { survei }\end{array}$ & Nasional & Nasional \\
\hline
\end{tabular}

Laporan \#NamaBaikKampus menyebutkan bahwa kebanyakan korban enggan untuk melaporkan secara resmi insiden yang dialaminya, bahkan mereka juga tidak menceritakannya kepada orang terdekat seperti keluarga atau teman. Adapun yang menjadi alasan utamanya adalah korban cenderung merasa malu, takut tidak dapat membuktikan kasusnya maupun maupun mempunyai kekhawatiran jika bercerita justru dianggap berlebihan. (Zuhra, 2019). Apa yang disampaikan dalam laporan \#NamaBaikKampus tersebut juga menjadi temuan Pendis Kemenag. Selain itu, Pendis Kemenag mengatakan bahwa kuatnya konsepsi patriarki dalam masyarakat kita membuat suatu kondisi di mana posisi perempuan dianggap lebih rendah dibanding laki-laki. Oleh karenanya, "perempuan seringkali direduksi menjadi objek seksual oleh kaum laki-laki”.

Selanjutnya, untuk mendapat informasi lebih lanjut terkait gambaran umum terkait fenomena kekerasan seksual di kampus, penulis juga mewawancarai 4 (empat) narasumber yang pada bagian metode sudah dijelaskan sebelumnya.

Menurut narasumber 1 (NR1), kekerasan seksual, termasuk yang terjadi di ranah perguruan tinggi diakibatkan oleh ketidaksadaran pelaku maupun korban bahwa hal tersebut adalah kekerasan seksual yang melanggar hak asasi manusia, khususnya perempuan. NR 1 menyebutkan bahwa seringkali korban tidak menyadari rayuan pacar/ teman laki-lakinya itu adalah "bahasa kuasa laki-laki”. Misalnya, korban sebenarnya tidak merasa nyaman ketika diajak untuk berhubungan intim, namun korban "tidak mampu/ berani menolak". 
Kemudian narasumber 2 (NR2), mengatakan bahwa berdasarkan pengalamannya mendampingi dan melakukan penelitian, kekerasan seksual di kampus terjadi karena laki-laki memiliki "self of entitlement" (merasa dirinya berhak) atas perempuan, terutama dalam beberapa kasus kekerasan seksual di kampus yang terjadi dalam hubungan berpacaran. Menurutnya, rasa memiliki hak atas pasangannya itu "sebenarnya konsep pola relasi kuasa yang tidak imbang antara laki-laki dan perempuan." Selain itu, NR2 menegaskan bahwa ada pandangan bahwa perempuan itu adalah objek seksualitas.

Selanjutnya narasumber 3 (NR3) mengatakan bahwa secara umum, kekerasan seksual itu terjadi karena "adanya relasi kuasa yang tidak seimbang, antara pelaku dan korban”. Menurutnya, perempuan menjadi korban kekerasan seksual tidak hanya disebabkan oleh relasi kuasa timpang saja, namun masyarakat kita yang patriarkal ini "memberi posisi istimewa pada laki-laki" dan kemudian "keistimewaan itu menjadikan perempuan sebagai properti atau objek seks."

Narasumber 4 (NR 4) menyatakan bahwa kekerasan seksual di kampus terjadi karena adanya "budaya permisif terhadap kekerasan seksual yang muasalnya itu dari ketimpangan gender, laki-laki dengan perempuan." Ia juga menyatakan bahwa anggapan "boys will be boys" menjadi bagian budaya masyarakat yang seakan dapat mengonfirmasi atau memfasilitasi "keleluasaan" laki-laki dalam memperlakukan perempuan. Baginya budaya tersebut memang merupakan bagian dari kehidupan bermasyarakat, di mana terbentuk suatu konsep dalam masyarakat bahwa laki-laki harus terlihat agresif atau terlihat jantan. Budaya yang sangat diskriminatif inilah yang kemudian membuat kasus-kasus kekerasan seksual terhadap perempuan terus terjadi, khususnya di kampusnya.

Untuk lebih jelasnya, penulis merangkum wawancara tersebut ke dalam matriks berikut (Tabel 4.2).

Tabel 4.2: Gambaran Umum Kekerasan Seksual di Kampus di Indonesia

\begin{tabular}{|c|c|c|c|}
\hline No & Sumber Data & Penyebab & Karakteristik \\
\hline 1 & Narasumber 1 & $\begin{array}{l}\text { Adanya relasi timpang } \\
\text { berbasis kuasa antara } \\
\text { korban dan pelaku akibat } \\
\text { konstruksi sosial budaya } \\
\text { yang dilatarbelakangi } \\
\text { oleh Budaya Patriarki. }\end{array}$ & $\begin{array}{l}\text { pelaku (laki-laki) maupun } \\
\text { korban (perempuan) tidak } \\
\text { memiliki kesadaran akan apa } \\
\text { yang dimaksud dengan } \\
\text { kekerasan seksual } \\
\text { - korban seringkali mengalami } \\
\text { viktimisasi ganda ketika } \\
\text { melaporkan insiden yang } \\
\text { dialaminya }\end{array}$ \\
\hline 2 & Narasumber 2 & $\begin{array}{l}\text { Pola relasi kuasa yang } \\
\text { tidak seimbang antara } \\
\text { laki-laki dan perempuan } \\
\text { termasuk dalam } \\
\text { memandang aspek }\end{array}$ & $\begin{array}{l}\text { - laki-laki merasa mempunyai } \\
\text { hak atas perempuan } \\
\text { - } \text { perempuan adalah objek } \\
\text { - } \text { seksualitas laki-laki } \\
\text { - korban seringkali tidak tidak }\end{array}$ \\
\hline
\end{tabular}


Community: Volume 6, Nomor 2, Oktober 2020

p-ISSN: 2477-5746 e-ISSN: 2502-0544

\begin{tabular}{|c|c|c|c|}
\hline & & seksualitasnya & $\begin{array}{l}\text { mempunyai akses terhadap } \\
\text { informasi terkait hak dan } \\
\text { pelayanan }\end{array}$ \\
\hline 3 & Narasumber 3 & $\begin{array}{l}\text { Karena adanya relasi } \\
\text { kuasa yang tidak } \\
\text { seimbang antara pelaku } \\
\text { dan korban yang } \\
\text { disebabkan oleh } \\
\text { masyarakat yang } \\
\text { patriarkal }\end{array}$ & $\begin{array}{l}\text { laki-laki merasa lebih istimewa } \\
\text { daripada perempuan } \\
\text { perempuan adalah properti } \\
\text { laki-laki dan tubuh perempuan } \\
\text { adalah objek seks. }\end{array}$ \\
\hline 4 & Narasumber 4 & $\begin{array}{l}\text { Adanya suatu budaya } \\
\text { yang sangat permisif } \\
\text { terhadap kekerasan } \\
\text { seksual yang muasalnya } \\
\text { itu dari ketimpangan } \\
\text { gender }\end{array}$ & $\begin{array}{l}\text { - laki-laki yang agresif adalah } \\
\text { gambaran laki-laki jantan } \\
\text { - perempuan (korban) tidak } \\
\text { berani menolak dan } \\
\text { melaporkan sementara korban } \\
\text { ingin didengar tanpa dihakimi. }\end{array}$ \\
\hline
\end{tabular}

\section{Pembahasan}

Dari semua uraian di atas, nampak bahwa temuan hasil penelitian dapat sepenuhnya mendukung argumen penulis. Seperti yang telah penulis jelaskan pada bagian permasalahan, teori paparan gaya hidup-aktivitas rutin belum mampu memberikan penjelasan tentang kebijakan yang mengatur ekspektasi peran dan kendala struktural, khususnya karena memang ada beberapa kebijakan kelembagaan atau peraturan yang ditetapkan oleh perguruan tinggi yang tidak dapat dihindari. Dari data sekunder, nampak bahwa kebanyakan kasus kekerasan seksual di kampus terjadi dalam aktivitas yang ditentukan oleh kampus, seperti perkuliahan, bimbingan tugas akhir maupun KKN.

Penelitian terkait kekerasan seksual di kampus memang masih sangat terfokus di AS, sehingga ada ketidaksesuaian dengan konteks Indonesia seperti budaya pesta pora dan mabuk-mabukan. Terlepas dari kondisi bahwa masyarakat Indonesia mayoritas beragama Islam, di mana minuman beralkohol diharamkan, secara umum minum minuman yang beralkohol bukan menjadi kebiasaan masyarakat kita. Selain itu, pesta yang digelar di kampus pada umumnya lebih mengarah pada pertunjukan seni yang mengharuskan adanya izin dari pihak lembaga perguruan tinggi.

Selanjutnya, dari hasil wawancara nampak bahwa budaya patriarki yang mengakar pada masyarakat kita menjadi penyebab utama mengapa kekerasan seksual di kampus terjadi. Secara umum, jika kita merujuk pada data sekunder yang telah dipaparkan sebelumnya, juga terlihat jelas bahwa kebanyakan pelaku adalah laki-laki dan korbannya adalah perempuan, meskipun ada juga korban laki-laki

Hasil temuan penelitian ini juga sejalan dengan penelitian terdahulu yang dilakukan oleh Uggen dan Blackstone (2004). Dalam penelitiannya tersebut, mereka membuat sebuah model konseptual relasi kuasa di tempat kerja, di mana stereotip 
gender muncul paling konsisten dengan distribusi perilaku sosial yang melecehkan. Model yang mereka buat tersebut menggabungkan kosep teori organisasi gender dari Acker (1990), teori pelecehan seksual oleh MacKinnon (1979; dikutip oleh Uggen dan Blackstone, 2004) dan teori relasi gender dari Connell (1995; dikutip oleh Uggen dan Blackstone, 2004). Dalam konteks penelitian yang dilakukan oleh penulis, beberapa narasumber menyebutkan bagaimana budaya patriarki menciptakan stereotip tertentu terhadap perempuan yang menyebabkan kekerasan seksual dapat terjadi.

Dari uraian hasil wawancara penulis terkait budaya patriarki serta penelitian Uggen tersebut, nampak bahwa teori paparan gaya hidup-aktivitas rutin juga belum mampu memberikan penjelasan bahwa budaya patriarki yang melekat suatu kelompok masyarakat memengaruhi perilaku sosial yang pada akhirnya juga dapat menaikkan risiko viktimisasi terhadap perempuan. Menurut penulis, hal ini juga dapat dimaknai bahwa jenis kelamin tertentu (baca: perempuan) juga menaikkan risiko viktimisasi seorang terhadap kekerasan seksual di kampus.

Sementara itu, dalam paradigma feminis radikal, seperti yang telah dijelaskan sebelumnya, patriarki adalah bentuk penindasan laki-laki terhadap perempuan yang paling mendasar. Konsep patriarki yang sangat mengakar di masyarakat kita akhirnya meligitimasi segala bentuk kekerasan terhadap perempuan. Perempuan dianggap sebagai properti milik laki-laki, yang mana harus dapat diatur sedemikian rupa, baik dalam berperilaku maupun berpakaian. Karakteristik tersebut muncul dalam pengalaman para narasumber yang sudah dipaparkan sebelumnya. Inilah mengapa kekerasan seksual di kampus juga dikategorikan ke dalam kekerasan berbasis gender, khususnya terhadap perempuan.

Berangkat dari pemaparan tersebut, maka penulis melihat bahwa kekerasan seksual di kampus dalam konteks Indonesia merupakan sebuah konsekuensi yang tak terhindarkan dari relasi kuasa antara laki-laki dan perempuan. Relasi kuasa ini terbentuk dari beragam praktik dan sudah mengakar dalam sistem tradisi budaya dan agama di mana perempuan patut direndahkan dan sudah sewajarnya berada di bawah kekuasaan laki-laki.

\section{PENUTUP}

\section{Limitasi Penelitian}

Dalam konteks artikel ini, sehubungan dengan belum tersedianya data nasional terkait kekerasan seksual di kampus, maka penulis hanya mengacu pada data sekunder yang diperoleh dari laporan \#NamaBaikKampus dan SK Dirjen Pendis Kemenag. Sementara itu, narasumber yang dipilih berada dalam lokasi geografis pulau jawa, di mana wilayah tersebut merupakan wilayah di mana kasus kekerasan seksual di kampus banyak dilaporkan merujuk pada laporan \#NamaBaikKampus. Meskipun tidak dapat mewakili keseluruhan perguruan tinggi yang ada di Indonesia, artikel ini diharapkan tetap dapat dijadikan referensi penelitian tentang topik terkait di masa mendatang. 


\section{Kesimpulan}

Berdasarkan hal tersebut, maka gambaran terkait kekerasan seksual di kampus memang lebih dapat dijelaskan dengan menggunakan perspektif feminis radikal. Argumen penulis adalah kekerasan seksual ini kejahatan yang sifatnya kompleks dan faktor penyebabnya tidak sekedar pelepasan kebutuhan seksual pelakunya saja. Ada bentuk-bentuk relasi kuasa yang terkadang terlihat jelas seperti aturan pelaksanaan jadwal kuliah ataupun KKN yang dapat menciptakan suatu kondisi di mana perempuan menjadi lebih rentan menjadi korban kekerasan seksual di kampus. Namun demikian, ada juga relasi kuasa yang tidak tidak terlihat jelas tetapi mempunyai pengaruh yang luar biasa sebagai faktor penyebab terjadinya kekerasan seksual di kampus, yaitu relasi kuasa yang diciptakan oleh budaya patriarki dalam masyarakat kita.

\section{DAFTAR PUSTAKA}

Acker, J. (1989) 'The problem with patriarchy', Sociology. doi: $10.1177 / 0038038589023002005$.

Banyard, V. L. et al. (2005) 'Revisiting unwanted sexual experiences on campus: A 12-year follow-up', Violence Against Women. doi: 10.1177/1077801204274388.

Bondurant, B. (2001) 'University women's acknowledgment of rape: Individual, situational, and social factors', Violence Against Woman. doi: 10.1177/10778010122182451.

Bourdieu, P. (1990) REPRODUCTION IN EDUCATION, SOCIETY AND CULTURE (second edition), London, England: SAGE Publications Ltd, 1990. xxvii+254 pp.

Brownmiller, S. (2005) Against Our Will: Men, Women and Rape (1975), Violence against women: Classic papers.

Bryson, V. and Bryson, V. (1992) 'Modern radical feminism: knowledge, language and patriarchy', in Feminist Political Theory. doi: 10.1007/978-1-349-22284-1_13.

Direktur Jenderal Pendidikan Islam Kementerian Agama RI (2019) SK Dirjen Pendis Nomor 5494 Tahun 2019 tentang Pedoman Pencegahan dan Penanggulangan Kekerasan Sesual pada Perguruan Tinggi Keagamaan Islam. Indonesia: Kementerian Agama.

Dziech, B. W. and Weiner, L. (1990) The Lecherous Professor: Sexual Harassment on Campus. 2nd edn. Urbana, Illinois: University of Illinois Press.

Elvey, K. (2016) Beyond the Party Lifestyle: A Quantitative Analysis of Sexual Victimization Among College Students. University of Cincinnati.

Eyre, L. (2000) 'The discursive framing of sexual harassment in a university community', Gender and Education. doi: 10.1080/713668301. 
FISHER, B. S. et al. (1998) 'CRIME IN THE IVORY TOWER: THE LEVEL AND SOURCES OF STUDENT VICTIMIZATION*', Criminology. doi: 10.1111/j.17459125.1998.tb01262.x.

Fitzgerald, L. F. et al. (1988) 'The incidence and dimensions of sexual harassment in academia and the workplace', Journal of Vocational Behavior. doi: 10.1016/00018791(88)90012-7.

Forbes, G. B. et al. (2005) 'Perceptions of dating violence following a sexual or nonsexual betrayal of trust: Effects of gender, sexism, acceptance of rape myths, and vengeance motivation', Sex Roles. doi: 10.1007/s11199-005-1292-6.

Franklin, C. A. et al. (2011) Risk Factors Associated with Women's Victimization. Huntsville, Texas. Available

at: http://www.crimevictimsinstitute.org/publications/?mode=view\&item=29.

Garlick, R. (1994) 'Male and female responses to ambiguous instructor behaviors', Sex Roles. doi: 10.1007/BF01420745.

Grauerholz, L. et al. (1999) 'There's safety in numbers: Creating a campus advisers' network to help complainants of sexual harassment and complaint receivers', Violence Against Women. doi: 10.1177/10778019922181563.

Holland, K. J. (2017) Sexual Assault Response Systems in an Evolving Legal Landscape: Implications for Reporting and Help-Seeking. The University of Michigan. Available at: https://deepblue.lib.umich.edu/bitstream/handle/2027.42/138486/kahollan_1.pdf?sequen $\mathrm{ce}=1$ \&isAllowed $=\mathrm{y}$.

Lee, J. et al. (2005) 'Attitudes toward rape: A comparison between Asian and caucasian college students', Violence Against Women. doi: 10.1177/1077801204271663.

McPhail, B. A. (2015) 'Feminist framework plus: Knitting feminist theories of rape etiology into a comprehensive model', Trauma, Violence, and Abuse. doi: $10.1177 / 1524838015584367$.

Murray, M. (1995) The Law of The Father? patriarchy in the transition from feudalism to capitalism. 1st edn. New York: Routledge.

Phillips, N. D. (2017) Beyond Blurred Lines: Rape Culture in Popular Media. Lanham, MD, USA: Rowman \& Littlefield Publishers.

Rentschler, C. A. (2014) 'Rape Culture and the Feminist Politics of Social Media', Girlhood Studies. doi: 10.3167/ghs.2014.070106.

Schwartz, M. D. and Pitts, V. L. (1995) 'Exploring a feminist routine activities approach to explaining sexual assault', Justice Quarterly. doi: 10.1080/07418829500092551.

Tong, R. (2009) Feminist thought: A more comprehensive introduction. 3rd edn. Boulder, Colo: Westview Press. 
Community: Volume 6, Nomor 2, Oktober 2020

p-ISSN: 2477-5746 e-ISSN: 2502-0544

Uggen, C. and Blackstone, A. (2004) 'Sexual harassment as a gendered expression of power', American Sociological Review. doi: 10.1177/000312240406900105.

Walby, S. (1989) ‘Theorising patriarchy’, Sociology. doi: 10.1177/0038038589023002004.

Walklate, S. (2007) Understanding Criminology: Current Theoretical Debates. London: McGraw-Hill Education.

Wallimann, I., Tatsis, N. C. and Zito, G. V. (1977) 'On Max Weber's Definition of Power', Journal of Sociology. doi: 10.1177/144078337701300308.

Whisnant, R. (2007) 'A Woman's Body is Like a Foreign Country: Thinking about National and Bodily Sovereignty', in DesAutels, P. and Whisnant, R. (eds) Global feminist ethics. Rowman and Littlefield, pp. 155-176.

Wolhuter, L., Olley, N. and Denham, D. (2008) Victimology: Victimisation and Victims' Rights. London: Routledge-Cavendish.

Zuhra, W. U. N. (2019) 'Testimoni Kekerasan Seksual: 174 Penyintas, 79 Kampus, 29 Kota', Tirto, 23 April. Available at: https://tirto.id/testimoni-kekerasan-seksual-174-penyintas79-kampus-29-kota-dmTW. 